\title{
The mountain tapir, endangered 'flagship' species of the high Andes
}

\author{
Craig C. Downer
}

The mountain tapir has already disappeared from parts of its range in the high Andes of South America and remaining populations are severely threatened by hunting and habitat destruction. With an estimated population of fewer than 2500 individuals, urgent measures are necessary to secure a future for the species. This paper presents an overview of the species throughout its range as well as some of the main results of the author's studies on tapir ecology. Finally, a plea is made for conservation action in Sangay National Park, which is one of the species's main strongholds.

\section{The mountain tapir: an overview}

The mountain tapir Tapirus pinchaque, was discovered by the French naturalist Roulin near Sumapaz in the eastern Andes of Colombia (Cuvier, 1829). The species is poorly known and most information has come from occasional observations or captures in the wild, reports from indigenous people in the species's range, and observations and studies in zoological parks (Cuvier, 1829; Cabrera and Yepes, 1940; Hershkovitz, 1954; Schauenberg, 1969; Bonney and Crotty, 1979).

Like lowland tapirs, mountain tapirs are primarily solitary, herbivorous browsers. They prefer moist habitats and bathe frequently. In spite of their thick woolly fur, they depend on cloud forests for shelter from the fierce storms that assail the Andes.

The most distinctive feature of the tapir family is the prehensile proboscis, which is employed in browsing, for orientation, bathing, and even squirting pursuers with water. Their sense of smell is keen (Walker, 1964) and allows the tapir to orientate at night or in dark forest. It usually moves with its head and trunk close to the ground ( $\mathrm{D}^{\prime}$ Aulaire and D'Aulaire, 1979; Janis, 1984).

The species has been recorded between 1400 and $4700 \mathrm{~m}$ in the Andes of Colombia and Ecuador and parts of northern Peru, but occurs most frequently between 2000 and 4300 m. However, it is rapidly disappearing (c) $1996 \mathrm{FFI}$ throughout its range. There is limited evidence to indicate that it may have occurred in western Venezuela about 20 years ago. However, Venezuelan authorities indicate a total absence of mountain tapir remains from Venezuelan territory, either from the recent or distant past (J. Paucar, F. Bisbal, O. Linares, pers. comms). Northern Peru contains only a small population (Grimwood, 1969).

In common with many montane forests world-wide, those of the Andes are being rapidly destroyed, causing the decline of the the tapirs (Poore, 1992). The mountain tapir is one of the world's most critically endangered large mammals; the IUCN/SSC Tapir Specialist Group estimates its population as fewer than 2500 individuals and that it has a greater than 20 per cent probability of disappearing within the next 20 years (Mace and Lande, 1991).

\section{A study of the mountain tapir}

The author first observed the mountain tapir in 1978 in Colombia's Las Hermosas Natural National Park (Downer, 1981) and since then has surveyed the species in northern Peru, Ecuador, Colombia and western Venezuela, listing about 20 remnant populations for the IUCN Species Survival Commission and Wildlife Conservation Society. Field observations formed a major part of the surveys 


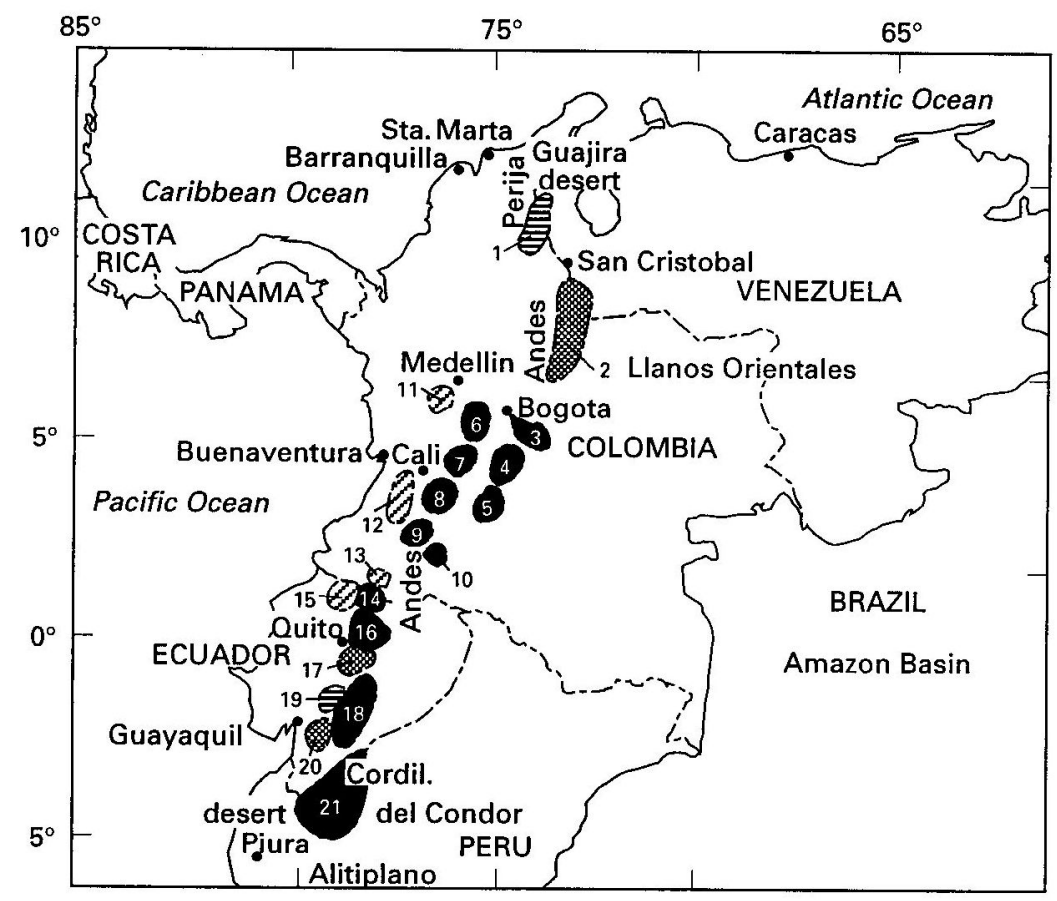

Occurrence reported in past 10 years

Possible former occurrence but no firm

Firm evidence for former occurrence but evidence doubtful occurrence now

Reported occurrence but needs verification

Figure 1. Mountain tapir distribution.

1. Perija PN, Venezuela, and Catatumbo Bari PNN, Colombia.

2. El Tama PN, Venezuela, and Tama PNN, El Cocuy PNN and Pisba PNN, Colombia.

3. Chingaza PNN, Colombia.

4. Sumapaz PNN, Colombia.

5. Cordillera Los Picachos PNN, Colombia.

6. Los Nevados PNN and Ucumari RP, Colombia.

7. Las Hermosas PNN, Colombia.

8. Nevado del Huila PNN, Colombia.

9. Purace PNN, Colombia.

10. Cueva de Los Guacharos PNN, Colombia.

11. Macizo de Tatama PNN, Colombia.

12. Farallones PNN and Munchique PNN, Colombia.

13. Galeras Flora and Fauna Sanctuary, Colombia.

14. El Angel RE, Ecuador.

15. Cotacachi Cayapas RE, Ecuador.

16. Cayambe-Coca RE, Sumaco-Napo PN and Antisana RE, Ecuador.

17. Cotopaxi PN, Ecuador.

18. Llanganatis Bosque Protector and Sangay PN, Ecuador.

19. Chimborazo Reserva de Producción de Fauna, Ecuador.

20. Cajas Area Nacional de Recreacion, Ecuador.

21. Podocarpus PN, Cordillera del Condor, and Zamora province, Ecuador; Piura state (national border),

Cajamarca state (national border), Tabaconas-Namballe RE and Cordillera del Condor, Peru.

PN, Parque Nacional; PNN, Parque Nacional Natural; RP, Regional Park; RE, Reserve Ecologica. 
and involved expeditions into parks and unprotected areas throughout the species's geographical range (Figure 1). This paper summarizes some of the findings from these surveys and from an intensive study in Sangay National Park in Ecuador.

\section{Sangay National Park}

Sangay National Park in the eastern Andes was designated a World Heritage Site largely because of its diversity of ecosystem types (Fundacion Natura, 1992; UNESCO, 1993). Recently expanded to nearly double its former size, the park covers more than $5180 \mathrm{sq} \mathrm{km}$ (Fundacion Natura, 1992; Figure 2). The mountain tapir occurs at higher elevations throughout the park, but is more frequent in the east. Sangay may be the species's most important stronghold.

Apart from the mountain tapir, mammals of note include the endangered spectacled bear Tremarctos ornatus, white-tailed deer Odocoileus virginianus, red brocket deer Mazama rufina, pudu Pudu mephistopheles, rabbit Sylvilagus braziliensis and a rare endemic subspecies of guinea-pig Cavia apertea patzelti. Pumas Felis concolor are common, particularly in areas where their numbers have increased in response to cattle invasion of the park.

Bird life includes the Andean condor Vultur gryphus, carunculated caracara Phalcobaenus carunculatus, red-backed hawk Buteo polysoma, white-collared swift Streptoprocne zonaris, sword-billed hummingbird Ensifera ensifera and the torrent duck Merganetta armata (Macey et al., 1976; Patzelt, 1989).

\section{Study site in Sangay National Park}

The main study site lies between 3300 and $4200 \mathrm{~m}$ in the Rio Culebrillas sector of the park $3 \mathrm{~km}$ west of the 5230-m-high Sangay Volcano and covers approximately $6 \times 9 \mathrm{~km}$ (Figure 2). To the west, the land is occupied almost exclusively by pastoral Puruhaes Indians and a family hacienda. The Amazon rain forests - or their remnants - extend east to the horizon.

(C) $1996 \mathrm{FFI}$, Oryx, 30 (1), 45-58

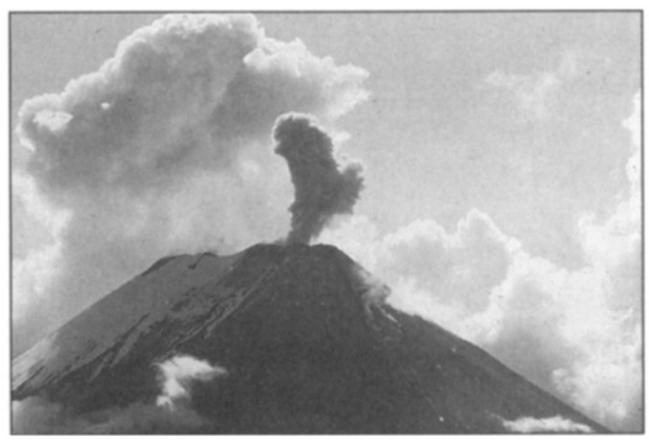

Sangay Volcano, $5230 \mathrm{~m}$, erupting. The Culebrillas study area frequently receives ashy fallout, killing its plants and animals, but enriching its soils for later ecological succession (Craig C. Downer).

The study area encompasses a broad, gently sloping river plain which extends along the Culebrillas River and its tributaries, including the Ramos-Tambo River. The plain is covered with grass and scrub while the adjacent slopes rise abruptly and are covered with dense cloud forest, giving way to bushy chaparral and treeless paramo at higher altitudes. Periodic flooding allows limited meadow development in the riverine areas but overgrazing by cattle is causing stream bank erosion.

A combination of heavy rains, fragile ashy soils and precipitous slopes make the area highly prone to earth slippage and erosion. The Sangay Volcano is a major influence on the successional level of the biotic community and over the centuries has enriched the soils of this region with minerals for hundreds of sq $\mathrm{km}$ around the volcano. The soils generally tend to be 'black Andean' with some rocky lithosols in the paramos (Macey et al., 1976). The ecological sere is young because when Sangay erupts the lava and ash kill all herbaceous species, many shrubs and trees and most animal life (Archivos Nuevo Mundo, Madrid; Lewis, 1950). The last major eruptions were in 1947 and 1988, but the latter did not deposit ash to the west and the study site was unaffected.

The vegetation comprises cloud forest and wet paramo (Ramsay, 1992), although for the purposes of this study five habitat types were identified: Andean forest, riverine meadow, chaparral, paramo and pampas. Montane 


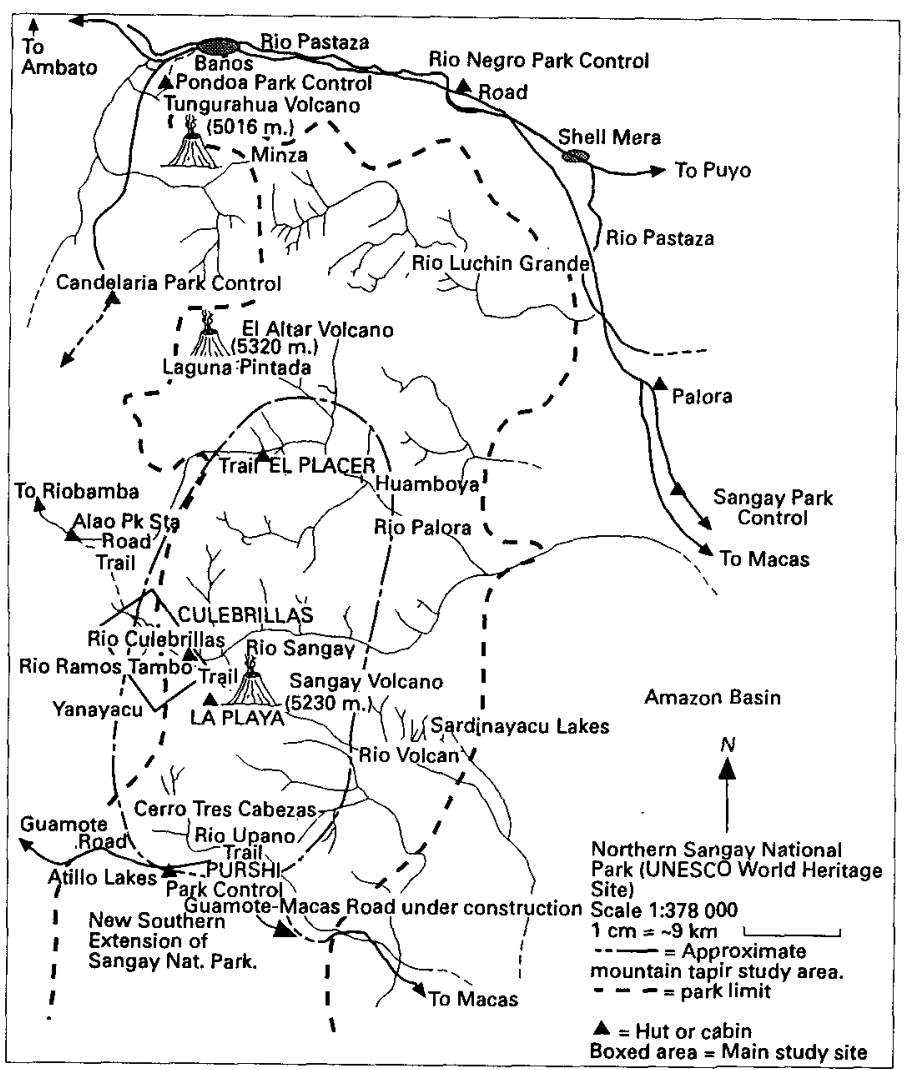

Figure 2. Sangay National Park, Ecuador, showing study site. cloud forest receives $2000-4000 \mathrm{~mm}$ precipitation annually and has a temperature range of $6-12^{\circ} \mathrm{C}$, while subalpine rain paramo receives $1000-2000 \mathrm{~mm}$ precipitation a year and has a temperature range of $3-6^{\circ} \mathrm{C}$ (Holdridge et al., 1971; Macey et al., 1976). Snow sometimes descends to $3500 \mathrm{~m}$ and Sangay peak is covered to its base during certain months. If total condensation on plants is included, the cloud forests probably receive at least double the above figures of moisture (Cavelier, 1991).

Culebrillas receives rain year-round, with storms arising frequently from the east, although relatively less between October to January (Macey et al., 1976; M. Mejia, Sangay National Park superintendent, pers. comm.).

\section{Methods}

In 1989 the author started a long-term study on the mountain tapir, which involved radio- tracking individuals, behavioural observations and a survey of food plants. The first success at radio-collaring the mountain tapir was achieved in the Culebrillas sector of Sangay National Park. Three adult mountain tapirs were captured, examined, radio-collared and released in December 1989. In July 1990, a female subadult was radio-collared in the same area. Another three mountain tapirs were captured and tracked, two in September and November 1992, and one in December 1993. Two of these were in an area known as La Playa near the base of Sangay Volcano, slightly higher $(c .3700 \mathrm{~m})$ than Culebrillas. The other was in a lower $(2800 \mathrm{~m})$ montane forest area to the north of the volcano, known as El Placer. Signals from the radio collars provided activity readings and allowed a number of topographical and ecological variables to be measured. Time-sequence data were also kept.

Eight vegetation transects were surveyed in the study area to produce a plant inventory 
and 37 faecal samples collected for dietary analysis. Germination experiments were conducted on tapir faeces at the Instituto Nacional de Investigacion Agropecuario (INIAP) experimental station south of Quito, where elevation and daily watering simulated cloud forest conditions. Throughout the study tapirs were observed whenever possible and their behaviour recorded, including territorial marking: rubbing tree trunks, urination, and dung piles.

\section{Results}

Vegetation surveys

A total of 264 species in 53 vascular plant families were recorded (Table 1). Several of these are believed to be new species including two species of Fuchsia and one new genus related to the filmy fern, Hymenophyllum The family Asteraceae predominated, with 27 genera and 59 species, and the Gramineae were well-represented, with 13 genera and 23 species.

The mountain tapir as consumer, germinator and seed disperser

Table 1 shows species that were observed to be eaten by the mountain tapir, or to germinate from its faeces. Figure 3 shows their ranking in order of dietary preference ratios (Crawley, 1983). This shows which food groups are most sought relative to their presence in the habitat, and is not to be confused with absolute quantity of consumption (Figure 4). The mountain tapir consumed 205 (77.7 per cent) of 264 identified vascular plant species from the Culebrillas study area. One-hundredand-ten ( 84 per cent) of 131 genera from 53 vascular plant families were represented in the diet. The mountain tapir clearly favoured certain taxa: 35 of 59 species (59 per cent) of Asteraceae (the most common family) were eaten and 13 of 14 recorded species of Rosaceae were taken. In absolute quantity, leaves of the silvery-leaved aster tree Gynoxys accounted for 24 per cent of the diet, while fern fronds accounted for 19 per cent (Figure 4). As indicated by the faecal analysis, these

() $1996 \mathrm{FFI}$, Oryx, 30 (1), 45-58

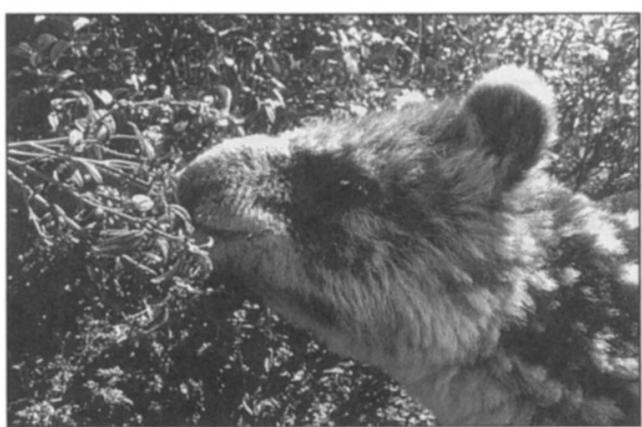

A 4-month-old, subadult mountain tapir eating leaves of Micronea crocea (Melastomataceae) in cloud forests of Ecuador, c. $3000 \mathrm{~m}$ (Craig C. Downer).

two categories comprised the greatest bulk of dietary consumption. Regarding preference ratios, however, mountain tapirs expend considerable effort to select certain plants, for example the legume Lupinus, which is rare in the habitat, while other food items are taken with much less frequency than would be expected from their abundance in the tapir's habitat (Figure 4).

The other three extant tapirs, Tapirus indicus, $T$. terrestris and T. bairdii, have also been reported to act as seed dispersers for many plant species (Williams and Petrides, 1980; Janzen, 1982; Fragosa, 1983; Williams, 1984; Bodmer 1989, 1991; Rodrigues et al., 1993). The results of the present study show that 42 per cent of the species of vascular plants eaten in the study area (32.6 per cent of those recorded) germinate in the mountain tapir's faeces (Table 1). This is comparable to information reported for Baird's tapir (Williams, 1984).

Observations of plants germinating from tapir dung and their proximity to mineral seeps, suggests that the mineral-rich faeces of the tapir, particularly those having recently visited mineral licks, provide a nutritive substrate for germinating seeds. There is some evidence that the mountain tapir is an obligate symbiont for certain species of high Andean plants, such as the Colombian wax palm Ceroxylon quindiuense ( $\mathrm{H}$. Acosta, pers. comm.).

Like other members of the Perissodactyla the mountain tapir possesses a post-gastric digestive system, which allows it to ingest large 
Table 1. Identified vascular and non-vascular plants in or near Culebrillas study area, Sangay National Park, that were seen to be eaten by mountain tapirs or were observed to be germinated from their faeces

\begin{tabular}{|c|c|c|c|c|c|c|c|}
\hline \multirow[b]{2}{*}{ Class } & \multirow[b]{2}{*}{ Family } & \multicolumn{2}{|l|}{ Found } & \multicolumn{2}{|l|}{ Eaten } & \multicolumn{2}{|c|}{ Germinated from faeces } \\
\hline & & Genera & Species & Genera & Species & Genera & Species \\
\hline All fungi & & 6 & 8 & 2 & 2 & 0 & 0 \\
\hline Muscopsida & & 6 & 9 & 6 & 8 & 1 & 1 \\
\hline Hepaticopsida & & 2 & 2 & 2 & 2 & 2 & 2 \\
\hline \multirow[t]{7}{*}{ Filcopsida } & Adiantaceae & 2 & 2 & 2 & 2 & 0 & 0 \\
\hline & Blechnaceae & 1 & 3 & 1 & 3 & 0 & 0 \\
\hline & Dennstaediaceae & 1 & 1 & 1 & 1 & 0 & 0 \\
\hline & Hymenophyllaceae & 1 & 4 & 1 & 3 & 0 & 0 \\
\hline & Lomariopsidaceae & 1 & 1 & 1 & 1 & 0 & 0 \\
\hline & Polypodaceae & 3 & 5 & 3 & 5 & 0 & 0 \\
\hline & Thelypteridaceae & 1 & 2 & 1 & 2 & 0 & 0 \\
\hline Lycopsida & Lycopodiaceae & 1 & 1 & 1 & 1 & 0 & 0 \\
\hline \multirow{2}{*}{ Sphenopsida } & Selaginellaceae & 1 & 1 & 1 & 1 & 0 & 0 \\
\hline & Equisetaceae & 1 & 1 & 1 & 1 & 1 & 1 \\
\hline \multirow[t]{5}{*}{ Liliopsida } & Bromeliaceae & 2 & 2 & 2 & 2 & 2 & 2 \\
\hline & Cyperaceae & 5 & 12 & 5 & 10 & 2 & 2 \\
\hline & Gramineae & 13 & 23 & 13 & 23 & 7 & 12 \\
\hline & Juncaceae & 2 & 4 & 2 & 2 & 0 & 0 \\
\hline & Iridaceae & 2 & 4 & 2 & 2 & 0 & 0 \\
\hline \multirow[t]{33}{*}{ Magnoliopsida } & Asteraceae & 27 & 59 & 20 & 35 & 6 & 7 \\
\hline & Campanulaceae & 1 & 2 & 1 & 2 & 1 & 2 \\
\hline & Valerianaceae & 1 & 8 & 1 & 6 & 1 & 3 \\
\hline & Gentianaceae & 3 & 7 & 2 & 4 & 0 & 0 \\
\hline & Loganiaceae & 1 & 2 & 1 & 2 & 1 & 1 \\
\hline & Lamiaceae & 2 & 2 & 2 & 2 & 2 & 2 \\
\hline & Plantaginaceae & 1 & 3 & 1 & 3 & 1 & 3 \\
\hline & Convolvulaceae & 1 & 1 & 1 & 1 & 0 & 0 \\
\hline & Solanaceae & 2 & 6 & 1 & 4 & 1 & 1 \\
\hline & Rubiaceae & 2 & 2 & 1 & 2 & 1 & 1 \\
\hline & Scrophulariaceae & 5 & 9 & 3 & 7 & 2 & 6 \\
\hline & Polygonaceae & 2 & 3 & 1 & 3 & 1 & 3 \\
\hline & Amaranthaceae & 1 & 1 & 1 & 1 & 1 & 1 \\
\hline & Caryophyllaceae & 2 & 4 & 1 & 2 & 1 & 1 \\
\hline & Cruciferae & 1 & 5 & 1 & 2 & 0 & 0 \\
\hline & Ericaceae & 4 & 8 & 4 & 5 & 4 & 5 \\
\hline & Elaeocarpaceae & 1 & 1 & 1 & 1 & 0 & 0 \\
\hline & Primulaceae & 1 & 1 & 1 & 1 & 0 & 0 \\
\hline & Actinidaceae & 1 & 1 & 1 & 1 & 0 & 0 \\
\hline & Passifloraceae & 1 & 1 & 1 & 1 & 1 & 1 \\
\hline & Piperaceae & 1 & 3 & 1 & 2 & 0 & 0 \\
\hline & Coriaraceae & 1 & 1 & 1 & 1 & 1 & 1 \\
\hline & Ranunculaceae & 1 & 4 & 1 & 4 & 0 & 0 \\
\hline & Geraniaceae & 1 & 4 & 1 & 3 & 1 & 1 \\
\hline & Oxalidaceae & 1 & 3 & 1 & 3 & 1 & 3 \\
\hline & Tropaeolaceae & 1 & 1 & 1 & 1 & 0 & 0 \\
\hline & Halogoraceae & 1 & 2 & 1 & 2 & 1 & 1 \\
\hline & Melastomataceae & 2 & 5 & 2 & 5 & 2 & 3 \\
\hline & Onagraceae & 2 & 7 & 1 & 5 & 1 & 2 \\
\hline & Polygalaceae & 1 & 2 & 1. & 2 & 0 & 0 \\
\hline & Vitaceae & 1 & 1 & 1 & 1 & 1 & 1 \\
\hline & Cunoniaceae & 1 & 2 & 1 & 2 & 0 & 0 \\
\hline & Fabaceae & 4 & 8 & 4 & 8 & 2 & 3 \\
\hline
\end{tabular}


Table 1. (continued).

\begin{tabular}{|c|c|c|c|c|c|c|c|}
\hline \multirow[b]{2}{*}{ Class } & \multirow[b]{2}{*}{ Family } & \multicolumn{2}{|l|}{ Found } & \multicolumn{2}{|l|}{ Eaten } & \multicolumn{2}{|c|}{ Germinated from faeces } \\
\hline & & Genera & Species & Genera & Species & Genera & Species \\
\hline & Rosaceae & 6 & 14 & 5 & 13 & 5 & 12 \\
\hline & Saxifragaceae & 2 & 4 & 1 & 3 & 1 & 3 \\
\hline & Loranthaceae & 2 & 2 & 1 & 1 & 0 & 0 \\
\hline & Apiaceae & 5 & 7 & 2 & 3 & 1 & 2 \\
\hline & Araliaceae & 1 & 2 & 1 & 2 & 0 & 0 \\
\hline \multicolumn{2}{|l|}{ Totals } & 145 & 283 & 120 & 217 & 56 & 89 \\
\hline \multicolumn{2}{|c|}{ Minus non-vascular plants } & -14 & -19 & -10 & -12 & -3 & -3 \\
\hline \multicolumn{2}{|c|}{ Total vascular plants } & 131 & 264 & 110 & 205 & 53 & 86 \\
\hline
\end{tabular}

quantities of coarse vegetation (Janis, 1976; Bodmer, 1990). Observations in this study of mountain tapirs eating tough, fibrous leaves of shrubs is consistent with this. The ingestion of a wide variety of plant species may serve to reduce toxicity by avoiding the accumulation of any particular toxin (Crawley, 1983). Mineral seeps and licks may also serve to neutralize plant toxins, although this remains to be proven (Acosta et al., in press).

As Eisenberg (1989) stated for tapirs in general and as Terwilleger (1978) found for $T$. bairdii, the current studies found mountain tapirs to be selective, although their choice is broad. The perambulating foraging style of the mountain tapir, as revealed by both radiotracking and field observation, may relate as much to predator avoidance as to optimal foraging, especially in regions where the puma population has increased due to the prevalence of livestock prey or where there is human disturbance.

By snapping off branches and toppling trunks, the mountain tapir makes additional forage available to smaller herbivores such as the diminutive Pudu mephistopheles (compare Williams, 1978, for T. indicus, and Williams, 1984 for T. bairdii). Along with its role as a seed disperser, this tends to substantiate the mountain tapir's keystone species role for the high northern Andes.

\section{The mountain tapir as prey}

The study showed that pumas both stalk and kill mountain tapir. Tapir fur was found in two of 15 puma scats, and puma prints following the exact course of some mountain tapir
Figure 3. Dietary item preference ratios for mountain tapirs. Preference ratio: $\geq 1$ = preferred; $\leq 1=$ avoided, i.e. eaten less frequently than encountered.

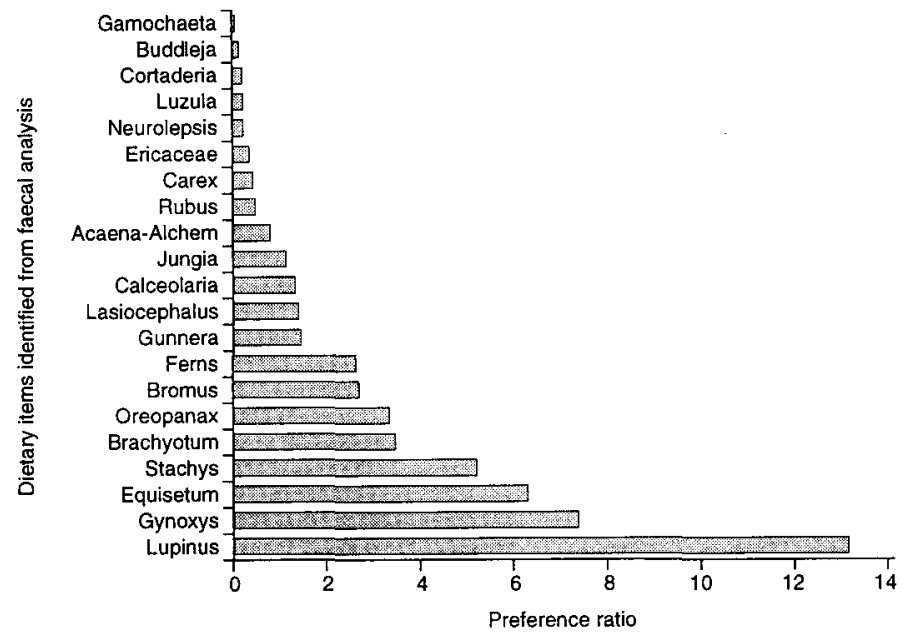




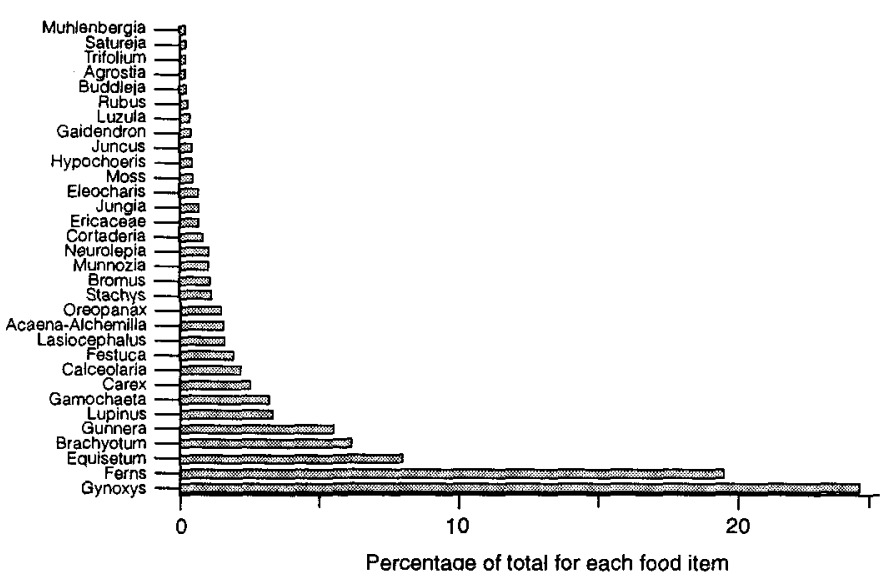

Figure 4. Relative proportion of food items in the diet of mountain tapir as determined by faecal analysis, Culebrillas sector and adjacent areas, Sangay National Park. No. faecal samples $=37$. prints were discovered on two separate occasions in widely separated areas. In the El Placer region of Sangay National Park adult tapirs were encountered bearing fresh scars, resembling the arched, thin claw-marks of the puma. Pumas stalking and killing mountain tapirs have also been reported from Podocarpus National Park (P. Moran pers. comm.) and in the Ucumari (H. Acosta, pers. comm.) and Las Hermosas (pers. obs.) parks of Colombia. Peyton (1980) documented the killing and devouring of mountain tapir by spectacled bear Tremarctos ornatus at $2200 \mathrm{~m}$ in Cajamarca, Peru. The presence of the spectacled bear was noted in nearly all areas inhabited by mountain tapirs that the author visited between 1978 and 1993.

In the Valladolid region of Loja state, southern Ecuador, unconfirmed reports of jaguar Panthera onca ascending to elevations occupied by the mountain tapir and killing them have been received from local hunters (G. Capa, pers. comm.). One major cause may be the destruction of forest habitats occurring in Ecuador's portion of the Amazon Basin (Simpson, 1990), which may also be driving Tapirus terrestris higher, thus causing possible competition with the mountain tapir. Local people and zoologists have suggested that hybridization occurs between the latter two congeners (G. Capa, P. Mena, L. Albuja, per. comms).

\section{Behaviour and habitat association}

Activity data (c. 3500 telemetric readings) were produced during the study. Tapirs aged 3-10 years slept most between midnight and dawn and had a peak of activity between 15.00 and $21.00 \mathrm{~h}$. Another consistent pattern
Table 2. Home ranges of mountain tapirs radio-collared and tracked in the Culebrillas sector, Sangay National Park

\begin{tabular}{llllll}
\hline Name & Sex & $\begin{array}{l}\text { Age } \\
\text { (years) }\end{array}$ & $\begin{array}{l}\text { Core } \\
\text { range (ha) }\end{array}$ & $\begin{array}{l}\text { Dates } \\
\text { tracked }\end{array}$ & $\begin{array}{l}\text { No. } \\
\text { locations }\end{array}$ \\
\hline Sambita & F & $3-6$ & 1,020 & $12 / 89-12 / 92$ & 205 \\
Roberto & M & $8-10$ & 846 & $12 / 89-12 / 91$ & 152 \\
Gabriel & M & $3-6$ & 775 & $12 / 89-12 / 92$ & 206 \\
Average core range & 880 & & & &
\end{tabular}

Tracking of these three adults and a subadult female was terminated due to their being poached. Culebrillas is heavily invaded by cattle. Three additional adult female mountain tapirs are being radio-tracked (June 1995) in two other areas of the park that are still cattle-free. 
was increased activity between dawn and $09.00 \mathrm{~h}$. During the rest of the daylight hours, activity decreased slightly, with a resting period between 12.00 and $15.00 \mathrm{~h}$. The two subadults tracked were predominantly inactive during all periods of the day, rather than showing the above adult pattern. The subadult female collared in Culebrillas, showed a more nocturnal pattern.

Activity during daylight and nocturnal hours was approximately equivalent. This is in distinct contrast to a predominantly nocturnal activity pattern among the other tapir species (Fradrich and Thenius, 1968; Terwilliger, 1978; Williams, 1978) and may be due to the higher, colder altitudes occupied by the mountain tapir, although $T$. bairdii has been recorded as high as $1500 \mathrm{~m}$ (D. Brooks, pers. comm.) and $T$. terrestris may ascend to similar heights (P. Mena, L. Albuja, O. Linares, pers. comms).

The adult female is often found in partial association with a male territory, but seems to have a generally larger home range overall (see Table 2). On several occasions a male and female were observed grazing or interacting together, but the adults are typically solitary, as is generally true of the Tapiridae (Walker, 1964; D'Aulaire and D'Aulaire, 1979).

The mountain tapir has a gestation period of 13 months (normally single birth) (Bonney and Crotty, 1979). Field observations in Sangay National Park showed that the female generally secludes herself when giving birth and during the first 6 months of nursing the calf, which is camouflaged with stripes and spots. Tracking indicated that the young stays close to the mother during the first year of life, particularly during the first 6 months.

Evidence of territorial marking was particularly strong in the Purshi sector of the park and may relate to a higher observed density of mountain tapirs in this previously virgin habitat within the park (now violated by a road) This relates to the longer history of ecosystem stability in this area, where volcanic disturbances are not as frequent as in Culebrillas (Macey et al., 1976).

During the study Sangay Volcano frequently showed signs of activity and its surges affected not only my radio-receptor, but also the tapirs themselves, causing increased activity and general restlessness.

Observations, and tracking records from hundreds of locations, revealed that average habitat use in five identified types of habitat was approximately 28.7 per cent in Andean forest, 22.9 per cent in riverine meadow, 22.3 per cent in chaparral, 19.7 per cent in paramo and 6.4 per cent in pampas. (For the purposes of this study pampas was defined as grassland created by burning and cattle occupation, and chaparral as the scrub ecotone between forest and paramo; riverine meadow occurred in all habitat types.) Subadults under 2 years spent most of their time concealed in forest and seldom ventured beyond the cover of the bushy chaparral. In the wet season greater use was made of Andean forest and less of paramo, while during the dry season greater use was made of the higher open paramo. The tapir's avoidance of cold by sheltering in forests in the wet season provides the primary explanation for this pattern. The fruiting of shrubby members of the Ericaceae and Bromeliaceae during the dry season may also help to explain the greater occupation of paramo then (C. Downer, pers. obs; cf. Klein, 1965).

The results of this study suggest that the Andean forest is the most important habitat type for the mountain tapir because of its role in providing food, shelter and concealment. It is precisely this ecotype that is being destroyed most rapidly (Poore, 1992; Cavelier and Etter, 1995; Associated Press, 1995).

\section{Threats facing Sangay National Park and mountain tapirs}

There are three main problems facing Sangay National Park and the mountain tapirs that live there: deforestation, encroachment by livestock and humans, and lack of awareness of the plight of the tapir.

\section{Deforestation}

Ecuador currently has the second highest rate of deforestation in Latin America and lost 48.7 
per cent of its forest in the period 1980-89 (Simpson, 1990). Sangay National Park is being invaded from all sides. Apart from Ecuador, the only other country still containing at least a minimum viable population (Soulé, 1986) of 1000 or more (author's estimate) tapirs is Colombia, which lost 65.4 per cent of its forest during the same period (Simpson, 1990). Deforestation in tropical mountains has proceeded at faster rates than in lowland tropical forests according to the Worldwatch Institute (Associated Press, 1995). Currently, an estimated $600-1000 \mathrm{sq} \mathrm{km}$ of montane forest in the three Andean cordilleras of Colombia are destroyed each year. If destruction continues at this rate, the mountain tapir and other high Andean-dependent species will soon disappear (Cavelier and Etter, 1995).

\section{Encroachment by livestock and hunters}

During the study period the number of cattle estimated by the author to be present in the study area and adjacent park areas towards the Sangay Volcano rose from 300 to over 1000 , and this trend shows no signs of slowing down (V. Alvarez, Sangay National Park superintendent, pers. comm., 1995). Because of the fragile soils and steep slopes, this is not only causing habitat conversion but severe erosion in places. Hunting is concomitant with livestock invasion, as is burning of forest and paramo to clear vegetation. All these activities are having devastating effects upon the mountain tapirs and their habitats.

Concomitant with lack of park protection, the mountain tapir suffers range constriction, exposure to disease (Hernandez-Camacho, pers. comm.) and increased risk from predation by both humans and pumas, although primarily the former. The tapir is a trophyspecies for many collectors, who pay large sums to local people to act as guides (A. Castellanos; A. Zegarra, pers. comms). These threats prevail in most areas where the mountain tapir survives and certainly in Sangay National Park.
Lack of awareness of the tapir's plight

National legislation is seldom enforced to protect the park, while the Puruhaes people appear to be dominated by a small group who show a marked reluctance to consider alternatives to increasing dependence on livestock agriculture. This is unfortunate, because the main value of the high Andes lies in its service as a watershed and wildlife reserve, similar to the very strictly protected reserves of the Incas (Vega, 1966; Morrison et al., 1976).

\section{Conservation requirements}

Mountain tapir numbers are falling below minimum population levels. The isolation of the remaining populations is leading to genetic bottlenecking and affords the species little future (Downer, 1995a, b). Population and concomitant habitat fragmentation is clearly leading rapidly to extinction and remedial action must be taken soon (Wilcox and Murphy, 1985; Janzen, 1986).

\section{Range protection}

Mountain tapirs are extremely vulnerable to invasion of their habitat (IUCN, 1972, 1982). The present author's observations indicate that after 10-20 per cent of their home range has been occupied, tapirs either die (mainly due to direct human detection and killing) or abandon their territory for safer ground, if possible (Figure 5). Extensive, persistent disturbance by humans and their livestock invading mountain tapir habitat in the high Andes is the primary cause of the decline of mountain tapirs (UN, 1978; Castaño-Uribe, 1991; Downer, 1995a, b). This highlights the necessity of protecting large areas of natural habitat where appropriate buffer zones isolate the core populations.

It is suggested that zones of limited agrarian development, where ecotourism supplements family income, be developed around mountain tapir areas, starting with Sangay National Park. These buffer zones would contain natural forests and paramos inhabited by the 
Figure 5. Effect of cattle invasion on home-range size and viability of three adult mountain tapirs, radio-tracked in 1990-93, Culebrillas sector, Sangay National Park. d, confirmed death of mountain tapir. (cf. Table 2).

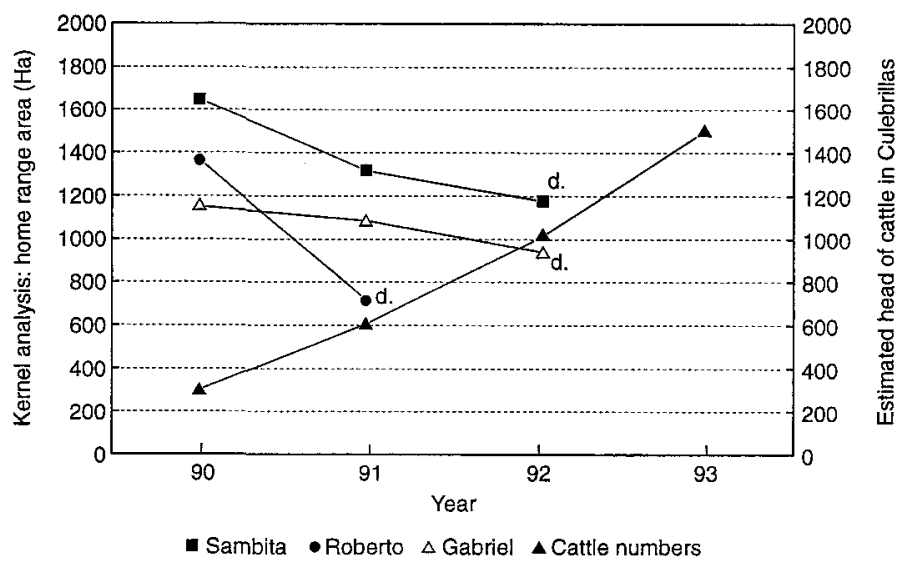

tribal communities are implicated in the destruction of the high-Andean ecosystem. International commerce in cattle, particularly bulls, raised in the region is also directly involved in the destruction of the ecosystem.

Highland Indians use the whole body of the mountain tapir: meat, hide and internal organs (including intestines made into a soup). They use the hooves and snout as medicinal remedies for epilepsy and heart problems. The latter are also sold in urban centres. This commerce is proving particularly devastating to surviving populations, such as those in northern Peru (A. Zegarra, pers. comm.).

Despite legal protection, there is little awareness or concern for the endangered status of this animal. Any form of harassment, killing or commerce involving the mountain tapir is illegal in all three countries of its range (IUCN, 1972, 1982). However, due to the longestablished tradition of mountain tapir hunting and given increasing human pressures, some conservationists consider the implementation of sustainable harvest models in buffer zones outside parks to be a more realistic way of saving this endangered species ( $R$. Bodmer, L. Salas, D. Brooks, pers. comms).

Certainly no realistic attempt to conserve the mountain tapirs of Sangay National Park can or should be made without the involvement of the local people. Conservation of the park should be part of a co-ordinated programme, including the restoration of eroded soils by agroforestry programmes using native trees and encouragement of ecotourism by 
which local people would benefit directly from their proximity to one of the world's most spectacular wildlife areas (Guinan, 1992).

Sangay National Park and its tapirs could be saved by means of a contractual agreement with local people, who would receive revenues generated by the park in exchange for withdrawing their cattle, ceasing to hunt within the park, and acting as park guides, hosts and protectors. It is critical that such a solution be implemented immediately.

\section{Maintenance of population strongholds}

From telemetric data collected between December 1989 and December 1992, the author estimated an average horizontal home range of 880 ha for the adult mountain tapir (Table 2). The highly accentuated topography of the habitat actually gives the mountain tapir a much greater surface area and vegetation resource (S. Matola, pers. comm.). Taking into account a conservative, inter-male mean range overlap of one-third, 587 ha represents the exclusive area required for each pair of breeding adults and their subadult offspring at any given time. Multiplying this figure by 500 (given sharing of territory by a male-female pair) gives a total of $293,500 \mathrm{ha}$, which would be the total area of suitable habitat needed for one minimum viable population of approximately 1000 breeding adults of equal sex ratio (based on interpretation of Soulé, 1986). An emphasis on protecting areas of suitable, contiguous habitat of at least this size and as nearly circular in shape as is consistent with natural wilderness boundaries is needed in order to make the most efficient use of conservation action (Boyce, 1992).

Much of Sangay National Park's 5180 sq km ha lies above $2000 \mathrm{~m}$ and the volcanic peaks tower over $5000 \mathrm{~m}$. This park could probably support a viable population of mountain tapirs; although 1000 is considered by some population biologists to be insufficient for the long-term survival of such a slowly reproducing mammal (Newmark, 1986). Given the level of cattle and hunter invasion with the associated habitat destruction in Sangay, the critical situation of the species can be well appreciated. The park could serve as a model example to other nations of effective conservation if a plan is successfully proposed and executed. Moreover, it could serve as a source of animals for restocking regions formerly inhabited by tapirs (Griffith et al., 1989). It appears that Venezuelan park authorities would like to accomplish reintroductions of mountain tapirs (E. Yerena, pers comm.).

\section{Conclusion}

Experiments and field observations have shown that the mountain tapir plays a vital ecological role in the high-Andean ecosystem. Its survival depends upon the preservation and restoration of the forest and paramos of the northern high Andes, which serve as vital watersheds for all the ecosystems lying below them, including those upon which humans depend. The mountain tapir is a large, easily recognizable animal and its image appears on the logo of Sangay National Park. It would be an ideal 'flagship' species for the conservation of both the park and the high northern Andes as a whole. I recommend that, as part of an international effort, a survey of the remaining high-Andean forest and paramo habitats be undertaken, including by satellite, in order to plan essential conservation efforts for the mountain tapir. These would benefit the many other species, including humans.

\section{Acknowledgements}

I wish to thank the following individuals and organizations that have helped over the past few years. The generous aid of NYZS-The Wildlife Conservation Society is much appreciated and I am grateful for the considerable help of the Ecuadorean National Parks and Wildlife Department and the various officials and park rangers and willing and able Puruhaes guides and assistants from the village of Alao. I am indebted for the very special support, faith and generosity of the Georgia Earth Alliance of Atlanta and its founder Gloria Wilkins. I greatly appreciate the support of the World Nature Associates, Silver Spring, Maryland, Chicago Zoological Society for their contributions and continued interest, the Los Angeles Zoological 
Foundation and the San Diego Zoological Society. I thank the High Desert Rainforest Group of Reno, Nevada, for their benefit reggae concert and contributions, the Nevada Humane Society, Ed Chipp, Ruska Bogdanovich, Chuck and Donna Steadman, and Ria Katz for their faith, concern for the tapirs, and generous contributions. Bernard Peyton provided valuable advice and equipment and the US Peace Corps provided me with my first encounter with the mountain tapirs. I thank the Missouri Botanical Garden Herbarium for help in identification, as well as the Catholic University Herbarium and INIAP of Quito. Also in Ecuador, thanks are due to the Escuela Politecnica Nacional and to the ecological groups Ecociencias and Cordavi of Quito, Baños 2000 of Tungurahua, and Arcoiris of Loja. I owe a special debt of gratitude to the School of Biological Sciences at the University College of North Wales, Bangor, particularly Ralph Oxley, Terry Williams and Rob McKay, for their help in data analysis. I thank my assistants, biologists Alfredo Lopez and Armando Castellanos-Peñafiel, for their courage and faith. I express my gratitude to my parents, Robert C. Downer and Alice G. Downer, who have greatly aided me, both morally and financially.

\section{References}

Acosta, H., Cavelier J. and Londona, S. In press. Aportes al Conocimiento de la Biologia de Tapirus pinchaque, en el Parque Regional Natural Ucumari. Biotropica.

Archivos Nuevo Mundo. 1492-Present. Madrid, Spain.

Associated Press. 1995 (February 12). Group urges worldwide protection for mountain ecosystems. Reno Gazette Journal, Reno, Nevada.

Bodmer, R.E. 1989. Frugivory in Amazonian Artiodactyla: evidence for the evolution of the ruminant stomach. Journal Zoology (London), 219, $457-467$.

Bodmer, R.E. 1990. Fruit patch size and frugivory in the lowland tapir (Tapirus terrestris). Journal Zoology (London), 222, 121-128.

Bodmer, R.E. 1991. Strategies of seed dispersal and seed predation in Amazonian ungulates. Biotropica, 23 (3), 255-261.

Bonney, S. and Crotty, M.J. 1979. Breeding the mountain tapir, Tapirus pinchaque, at the Los Angeles Zoo. International Zoo Yearbook, 19, 198-200.

Boyce, M.S. 1992. Population Viability Analysis. Ann. Rev. Ecol. Syst. 23, 481-506.

Cabrera, A. and Yepes, J. 1940. Mamiferos SudAmericanos. Casa Argentina de Editores, Buenos Aires, Argentina.
Castaño-Uribe, C. 1991. Hombres de Ladera y Camino Arriero. In Bosques de Niebla de Colombia (ed. C. U. Hurtado), pp. 171-182. Banco Occidental Credencial, Bogota, Colombia.

Cavelier, J. 1991. El Ciclo del Agua en Bosques Montanos. In Bosques de Niebla de Colombia (ed. C. U. Hurtado), pp. 69-84. Banco Occidental Credencial, Bogota, Colombia.

Cavelier, J. and Etter, A. 1995. Deforestation of montane rain forests in Colombia as a result of illegal plantation of opium (Papaver somniferum). In Neotropical Montane Forests: Biodiversity and Conservation. Proceedings of a conference, June 1993, New York Botanical Garden, Bronx, New York.

Crawley, M.J. 1983. Herbivory: The Dynamics of Animal-Plant Interaction. Blackwell Scientific Publications, Oxford.

Cuvier, M. le Baron. 1829. Rapport sur un Memoire de M. Roulin, ayant pour objet la decouverte d'une nouvelle espece de Tapir dans l'Amerique du Sud, fait a l'Academie royal des Sciences. Annales des Sciences Naturelles, 17, 107-112

D'Aulaire, E. and D'Aulaire, P.O. 1979. Is this the creature time forgot? International Wildlife, 9 (1), 29-32.

Downer, C.C. 1981. A paramo paradise: Colombia's Las Hermosas National Park. Americas, pp. 18-25. Organization of American States, Washington, DC.

Downer, C.C. 1991. Andean Highway Violates International Treaty. E-Sheet, 2 (52). Environmental News Service, Vancouver, Canada.

Downer, C.C. 1995a. The gentle botanist. Wildlife Conservation, New York Zoological Society, Bronx, New York, August, 30-35.

Downer, C.C. 1995b. Road alert. Wildlife Conservation, New York Zoological Society, Bronx, New York, October, 10.

Eisenberg, J.F. 1989. Mammals of the Neotropics. The North. Neotropics. Vol. 1. University of Chicago Press, Chicago.

Fradrich, M. and Thenius, E. 1968. Tapirs. In Grzimek's Animal Life Encyclopedia (ed. H.C. B. Grzimek), pp. 17-33. Van Nostrand-Reinhold, New York.

Fragosa, J.M. 1983. The ecology and behaviour of Baird's tapir in Belize. BSc Thesis. Trent University, Peterborough, Ontario, Canada.

Fundacion Natura. 1992. Parques Nacionales del Ecuador y Otras Areas Naturales Protegidas. Fundacion Natura and Ministry of Agriculture and Livestock, Quito, Ecuador.

Griffith, B., Scott, J.M., Carpenter, J.W. and Reed, C. 1989. Translocation as a species conservation tool: status and strategy. Science, $245,477-480$.

Grimwood, I.R. 1969. Notes on the Distribution and 
Status of some Peruvian Mammals 1968. Special publication 21, American Committee for International Wildlife. Protection and New York Zoological Society, Bronx, NY, USA.

Guinan, Y.N. 1992. Resolving people-park conflicts at Sangay National Park, Ecuador: a case study of Alao. MSc dissertation. University College of North Wales, Bangor, UK.

Hershkovitz, P. 1954. Mammals of northern Colombia, preliminary report No. 7: Tapirs (genus Tapirus) with a systematic review of American species. Proc. U.S. Nat. Mus. 103, 465-496.

Holdridge, L.R., Grenke, W.C., Hatheway, W.H., Liang, T. and Tossi, Jr, J.A. 1971. Forest Environments in Tropical Life Zones. Pergamon Press, Oxford.

IUCN. 1972. Red Data Book. IUCN-The World Conservation Union, Morges, Switzerland.

IUCN. 1982. Red Data Book. IUCN-The World Conservation Union, Gland, Switzerland.

Janis, C. 1976. The evolutionary strategy of the Equidae and the origins of rumen and caecal digestion. Evolution, 30, 757-774.

Janis, C. 1984. Tapirs as living fossils. In Living Fossils (eds N. Eldredge and S. M. Stanley) Springer Verlag, New York and Berlin.

Janzen, D.H. 1982. Seeds in tapir dung in Santa Rosa National Park, Costa Rica. Brenesia, No. 19/20, 129-135.

Janzen, D.H. 1986. The eternal external threat. In Conservation Biology: The Science of Scarcity and Diversity (ed. M. E. Soulé), pp. 286-303. Sinauer, Sunderland, Mass. USA.

Klein, D.R. 1965. Ecology of deer range in Alaska. Ecol. Monogr. 35, 259-284.

Lewis, G.E. 1950. Sangay, fire-breathing giant of the Andes. National Geographic Magazine, 97, 117-138.

Mace, G.M. and Lande, R. 1991. Assessing extinction threats: toward a re-evaluation of IUCN threatened species categories. Conservation Biology, 5, 148-157.

Macey, A., Armstrong, G., Gallo, N. and Hall, M.J. 1976. Sangay: Un Estudio de Las Alternativas de Manejo. Depto. de Parques Nacionales y Vida Silvestre. Direccion General de Desarrollo Forestal, Quito, Ecuador.

Martin, P.S. and Wright, H.E. 1967. Pleistocene Extinctions. Yale University Press, New Haven.

Morrison, T. and Editors of Time Life. 1976. The Andes. Time Life International, Amsterdam.

Newmark, W.D. 1986. Mammalian richness, colonization and extinction in western North American National Parks. PhD thesis, University of Michigan, Ann Arbor, Michigan, USA.

Patzelt, E. 1989. Fauna del Ecuador. Banco Central de
Ecuador, Quito.

Peyton, B. 1980. Ecology, distribution and food habits of spectacled bears, Tremarctos ornatus, in Peru. Journal of Mammalogy, 61, 639-652.

Poore, D. 1992. Guidelines for Mountain Protected Areas. Commission on National Parks and Protected Areas. IUCN, Gland, Switzerland.

Ramsay, P.M. 1992. The Paramo vegetation of Ecuador: the community ecology, dynamics and productivity of tropical grasslands in the Andes. PhD thesis. University College of North Wales, Bangor, UK.

Rodrigues, M.R., Olmos, F. and Galetti, M. 1993. Seed dispersal by tapir in southeastern Brazil. Mammalia, 57, 460-461.

Schauenberg, P. 1969. Contribution a l'etude du tapir pinchaque, Tapirus pinchaque. Revue Suisse de Zoologie, 76, 211-256.

Simpson, S. 1990. The Times Guide To The Environment. Times Books, London.

Soulé, M.E. 1986. Viable Populations. Cambridge University Press, Cambridge.

Terwilleger, V. 1978. Natural history of Baird's tapir on Barro Colorado Island. Biotropica, 10, 211-220.

UN. 1978. United Nations Conference on Desertification: Roundup, Plan of Action and Resolutions. UN, New York.

UNESCO. 1993. Convention Concernant La Protection du Patrimonie Culturel et Naturel. Carthagene, Colombie (6-11 December 1993), p. 16. UNESCO, Paris, France.

Vega, G. de la. 1966. Royal Commentaries of the Incas and General History of Peru. University of Texas Press, Austin.

Walker, E.P. 1964. Mammals of the World, Vol. 2. John Hopkins Press, Baltimore.

Wilcox B.A. and Murphy, D.D. 1985. Conservation strategy: the effects of fragmentation on extinction. Am. Nat. 125, 879-887.

Williams, K.D. 1978. Aspects of the ecology and behavior of the Malayan tapir (Tapirus indicus Desmarest) in the national parks of western Malaysia. MSc thesis, Dept. Fish and Wildlife, Michigan State University, USA.

Williams, K.D. 1984. The Central American Tapir (Tapirus bairdii Gill) in northwestern Costa Rica. Dissertation Abstract International, B 45 (4), 1075.

Williams, K.D. and Petrides, G.A. 1980. Browse use, feeding behaviour and management of the Malayan tapir. Journal of Wildlife Management, 44, 489-494.

Craig C. Downer, School of Biological Sciences, University College of North Wales, Bangor, Gwynedd LL57 2UW, UK. Current address: PO Box 456, Minden, NV 89423, USA 